\title{
PENGGUNAAN METODE SAS DALAM PENINGKATAN KEMAMPUAN MEMBACA PERMULAAN PADA SISWA KELAS I SDN 106162 MEDAN ESTATE
}

\author{
Syarifah Hasibuan \\ Surel: syarifah_hasibuan@gmail.com
}

\begin{abstract}
This classroom action research aims to determine the application of method learning strategies SAS (Structural Synthetic Analysis) Class I students Even Elementary Semester Neg. 106162 Medan Estate, To find out the improvement in reading of class students in the even semester of SD.Neg 106162 Medan Estate through SAS method learning strategies; and how is the response of even class I Neg students. 106162 Medan Estate in reading through the application of learning strategies with the SAS method. This study used an interactive qualitative method and a class action research approach conducted in 2 cycles. Each cycle includes planning, implementation, observation and reflection. the subjects of this class action research are even class I students of Neg semester. 106162 Medan Estate. While the object is the SAS Method. From the research conducted by examining the initial condition of students as measured by reading tests and the results of classroom action research with 2 cycles. Based on data analysis, it can be concluded that in cycle 1 student learning completeness in this material the average value is only 66.50 while in cycle 2 by applying learning strategies with SAS methods increasing reaching an average value of 90.00 Student responses also increase, observational data of teacher activity from $59.72 \%$ in cycle 1, increasing in cycle 2 to $93.06 \%$.
\end{abstract}

Keywords : Reading Beginning, Ability, SA Method

\begin{abstract}
ABSTRAK
Penelitian tindakan kelas ini bertujuan Untuk mengetahui penerapan strategi pembelajaran method SAS (Struktural Analisis Sintetik) siswa Kelas I Semester Genap SD Neg. 106162 Medan Estate, Untuk mengetahui peningkatan membaca siswa kelas Ia semester genap SD. Neg 106162 Medan Estate melalui strategi pembelajaran method SAS; dan Bagaimana respon siswa kelas I semester genap Neg. 106162 Medan Estate dalam membaca melalui penerapan strategi pembelajaran dengan method SAS. Penelitian ini menggunakan metode kualitatif interaktif dan pendekatan penelitian tindakan kelas PTK (Class Action Research) yang dilakukan dengan 2 siklus. Setiap siklus meliputi perencanaan, pelaksanaan, observasi dan refleksi. subyek penelitian tindakan kelas ini adalah siswa kelas I semester genap Neg. 106162 Medan Estate. Sedangkan obyeknya adalah Methode SAS. Dari penelitian yang dilakukan dengan meneliti kondisi awal siswa yang diukur dengan alat tes membaca dan hasil penelitian tindakan kelas dengan 2 siklus. Berdasarkan analisis data dapat disimpulkan bahwa pada siklus 1 ketuntasan belajar siswa pada materi ini nilai rata-rata hanya 66,50sedangkan pada siklus 2 dengan menerapkan strategi pembelajaran dengan method SAS meningkat mencapai nilai rata-rata 90,00 Respon siswa juga meningkat, data hasil observasi terhadap aktivitas guru dari 59,72\% pada siklus 1, meningkat pada siklus 2 menjadi $93,06 \%$.
\end{abstract}

Kata Kunci : Membaca Permulaan, kemampuan, Metode SA 


\section{PENDAHULUAN}

Membaca bukan hanya mengucapkan bahasa tulisan atau lambang bunyi bahasa, melainkan juga menanggapi dan memahami isi bahasa tulisan. Dengan demikian membaca merupakan suatu bentuk komunikasi tulis. A.S Broto dalam Mulyono Abdurrachman (2003:200) Membaca merupakan aktivitas kompleks yang memerlukan sejumlah besar tindakan terpisahpisah, mencakup penggunaan pengertian, khayalan, pengamatan dan ingatan. Sudarso, dalam Mulyono Abdurrachman (2003:200). Membaca merupakan pengenalan simbol-simbol bahasa tulis yang merupakan stimulus yang membantu proses mengingat tentang apa yang dibaca, untuk membangun suatu pengertian melalui pengalaman yang telah dimiliki. Bond dalam Mulyono Abdurrachman (2003:200), berdasarkan pengertian-pengertian membaca yang telah dikemukakan dapat disimpulkan bahwa membaca merupakan aktivitas kompleks yang menghasilkan simbol-simbol bahasa tulis melalui proses mengingat untuk memahami isi bahasa tulisan. Orang dapat membaca dengan baik jika mampu melihat huruf-huruf dengan jelas, mampu menggerakkan mata secara lincah, mengingat simbolsimbol bahasa dengan tepat, dan memiliki penalaran yang cukup untuk memahami bacaan. Meskipun tujuan akhir membaca adalah untuk memahami isi bacaan, tujuan semacam itu ternyata belum dapat sepenuhnya dicapai oleh anak-anak, terutama pada saat awal belajar membaca. Banyak anak yang dapat membaca secara lancar suatu bahan bacaan tetapi tidak memahami isi bacaan tersebut. Hal ini menunjukkan bahwa kemampuan membaca bukan hanya terkait erat dengan kematangan gerak motorik mata, tetapi juga tahap perkembangan kognitif. Mempersiapkan anak untuk belajar membaca merupakan suatu proses yang panjang. Dengan demikian, proses mempersiapkan anak-anak untuk belajar membaca harus dimulai sedini mungkin. Empat aspek keterampilan berbahasa dalam dua kelompok kemampuan (Muchlisoh, 1992:119): Keterampilan yang bersifat menerima (reseptif) yang meliputi ketrampilan membaca dan menyimak, Keterampilan yang bersifat mengungkap (produktif) yang meliputi ketrampilan menulis dan berbicara. Pembelajaran Bahasa Indonesia di Sekolah Dasar (SD) bertujuan meningkatkan kemampuan siswa berkomunikasi secara efektif, baik lisan maupun tertulis, baik dalam situasi resmi non resmi, kepada siapa, kapan, dimana, untuk tujuan apa. bertumpu pada kemampuan dasar membaca dan menulis juga perlu diarahkan pada tercapainya kemahirwacanaan.Pada tingkatan membaca permulaan, pembaca belum memiliki keterampilan kemampuan membaca yang sesungguhnya, tetapi masih dalam tahap belajar untuk memperoleh keterampilan atau 
kemampuan membaca. Membaca pada tingkatan ini merupakan kegiatan belajar mengenal bahasa tulis. Melalui tulisan itulah siswa dituntut dapat menyuarakan lambang-lambang bunyi bahasa tersebut, untuk memperoleh kemampuan membaca diperlukan tiga syarat, yaitu kemampuan membunyikan: (a) lambang-lambang tulis, (b) penguasaan kosakata untuk memberi arti, dan (c) memasukkan makna dalam kemahiran bahasa. Membaca permulaan merupakan suatu proses keterampilan dan kognitif. Proses keterampilan menunjuk pada pengenalan dan penguasaan lambang-lambang fonem, sedangkan proses kognitif menunjuk pada penggunaan lambang-lambang fonem yang sudah dikenal untuk memahami makna suatu kata atau kalimat (Nuryati, 2007). Pembelajaran membaca permulaan diberikan di kelas I dan II. Tujuannya adalah agar siswa memiliki kemampuan memahami dan menyuarakan tulisan dengan intonasi yang wajar, sebagai dasar untuk dapat membaca lanjut. Tujuan membaca permulaan juga dijelaskan dalam (Depdikbud, 1994:4) yaitu agar "Siswa dapat membaca katakata dan kalimat sederhana dengan lancar dan tepat“. Pelaksanaan membaca permulaan di kelas I Sekolah Dasar dilakukan dalam dua tahap, yaitu membaca periode tanpa buku dan membaca dengan menggunakan buku. Pembelajaran membaca tanpa buku dilakukan dengan cara mengajar dengan menggunakan media atau alat peraga selain buku misalnya kartu gambar, kartu huruf, kartu kata dan kartu kalimat. Pembelajaran membaca dengan buku merupakan kegiatan membaca dengan menggunakan buku sebagai bahan pelajaran. Metode SAS adalah metode pembelajaran membaca yang dimulai dengan langkah bercerita sambil menunjukkan gambar pendukung. Setelah itu siswa diajak untuk membaca gambar tersebut, yang dilanjutkan dengan membaca kalimat. Siswa berlatih membaca kalimat tanpa bantuan gambar (proses struktural). Kalimat tersebut lalu dianalisis menjadi kata, suku kata, huruf-huruf (proses analitik). Langkah terakhir adalah menggabungkan kembali huruf-huruf menjadi suku kata, suku kata menjadi kata, dan kata-kata menjadi kalimat (proses sintetik). Guru bercerita atau berdialog dengan siswa, Memperlihatkan gambar yang berhubungan dengan isi cerita, Menulis beberapa kalimat sebagai kesimpulan dari isi cerita, Menulis satu kalimat yang diambil dari isi cerita, Menulis kata-kata sebagai uraian dari kalimat, Menulis sukusuku kata sebagai uraian dari katakata, Menuliskan huruf-huruf sebagai uraian dari suku-suku kata, Mensintesiskan huruf-huruf menjadi suku-suku kata dan Menyatukan kata-kata menjadi kalimat. Pada tahap buku pembelajarannya dilaksanakan dengan cara sebagai berikut: 1). Merekam bahasa siswa Bahasa yang digunakan siswa dalam 
percakapan direkam untuk digunakan sebagai bahan bacaan, 2). Menampilkan gambar sambil bercerita, 3). Membaca Gambar Misalnya: guru memperlihatkan gambar seorang anak sedang memegxang sapu sambil mengucapkan kalimat "Nino menyapu kelas", 4). Membaca gambar dengan kartu kalimat. Setelah siswa dapat membaca tulisan dibawah gambar, guru menempatkan kartu kalimat dibawah gambar untuk memudahkan pelaksanaan dapat digunakan media berupa papan flannel, kartu kalimat, kartu kata, kartu suku kata, kartu huruf dan kartu gambar. Dengan menggunakan media tersebut untuk menguraikan dan menggabungkan akan lebih mudah, dan 5). Membaca kalimat secara struktural Setelah siswa dapat membaca tulisan dibawah gambar, gambar dilepas sehingga siswa dapat membaca tanpa dibantu dengan gambar.

\section{METODE PENELITIAN}

$\begin{array}{rcr}\text { Dalam } & \text { penelitian ini } \\ \text { menggunakan } & \text { yang }\end{array}$
didasarkan atas konsep pokok bahwa penelitian tindakan terdiri dari empat komponen pokok yang juga menunjukkan langkah pelaksanaan penelitian, yaitu: 1. Perencanaan atau Planning 2. Tindakan atau Acting 3. Pengamatan atau Observasing dan Refleksi atau Reflekting (Arikunto, 2002: 83).

Tempat yang peneliti jadikan pelaksanaan penelitian tindakan kelas ini adalah di SD Negeri
106162 Medan Estate Tempat penelitian berlokasi di SD Negeri 106162 Medan Estate Kabupaten Deli Serdang, dimana tempat ini sekaligus tempat peneliti melaksanakan tugas mengajar. Alasan peneliti memilih tempat tersebut adalah: 1) Lokasinya dekat dengan rumah peneliti sehingga mudah dijangkau, 2) Peneliti saat ini menjadi salah satu guru yang mengajar di sekolah tersebut sehingga memudahkan peneliti untuk melaksanakan penelitian tindakan kelas ini. Penelitian tindakan kelas ini dilaksanakan dalam waktu yang cukup singkat yaitu dalam waktu Selama 3 bulan.

Penelitian ini adalah seluruh siswa kelas I SD Negeri106162 Medan Estate Kabupaten Deli Serdang sebanyak 30 siswa, Pengambilan subyek penelitian ini didasarkan pada kondisi kelas yang diampu peneliti sekaligus mampu mewakili siswa kelas I secara keseluruhan.

\section{Siklus I}

Persiapan yang dilakukan untuk proses penelitian tindakan kelas ini adalah mendata seberapa banyak anak yang kesulitas belajar membaca.

$$
\text { Pelaksanaan Siklus I. 1) }
$$

Tahap Perencanaan Tindakan Anak anak yang akan ditingkatkan prestasi belajar membaca dengan menggunakan Methode SAS. Adapun langkah yang dilakukan pada tahapan ini antara lain: 
Syarifah Hasibuan: Penggunaan Metode SAS (Struktural ...

a. Pengumpulan data diri anak yang prestasi belajar membacanya rendah.

b. Mengidentifikasi masalah yang dihadapi siswa dan memecahkannya.

c. Menyusun Rencana Pelaksanaan Pembelajaran (RPP) yang tepat yakni Pembelajaran dengan Methode SAS.

Tahapan Pelaksanaan Tindakan

a. Guru menerapkan metode pembelajaran dengan Methode SAS.

b. Siswa belajar dalam situasi pembelajaran membaca dengan Methode SAS. c) Memantau perkembangan prestasi belajar yang terjadi pada anak.

Tahapan Observasi. Tindakan guru memonitor dan membantu siswa jika menemui kesulitan selama pengajaran membaca dengan Methode SAS.

Tahapan Refleksi Tahapan Rekomendasi Mengadakan refleksi dan evaluasi dari kegiatan 1), 2), 3). Berdasarkan hasil refleksi dan evaluasi siklus I dibuat siklus II yang meliputi: Tahap Perencanaan Tindakan, Tahap Pelaksanaan Tindakan, Tahap Observasi dan Tahap Refleksi.

Tahapan Refleksi Tahapan Rekomendasi Tahap ini dilakukan dengan merumuskan tindakan pembelajaran dengan Methode SAS yang tepat untuk meningkatkan prestasi belajar membaca pada siswa

kelas I SDN 106162 Medan Estate Kabupaten Deli Serdang.

\section{Siklus II}

Persiapan yang dilakukan untuk proses penelitian tindakan kelas ini adalah mendata seberapa banyak anak yang kesulitas belajar membaca.

Pelaksanaan Siklus I. Tahap Perencanaan Tindakan Anak - anak yang akan ditingkatkan prestasi belajar membaca dengan menggunakan Methode SAS. Adapun langkah yang dilakukan pada tahapan ini antara lain :

a. Pengumpulan data diri anak yang prestasi belajar membacanya rendah.

b. Mengidentifikasi masalah yang dihadapi siswa dan memecahkannya.

c. Menyusun Rencana Pelaksanaan Pembelajaran (RPP) yang tepat yakni Pembelajaran dengan Methode SAS.

Tahapan Pelaksanaan Tindakan

a. Guru menerapkan metode pembelajaran dengan Methode SAS.

b. Siswa belajar dalam situasi pembelajaran membaca dengan Methode SAS.

c. Memantau perkembangan prestasi belajar yang terjadi pada anak.

Tahapan Observasi. Tindakan guru memonitor dan membantu siswa jika menemui kesulitan selama 
pengajaran membaca dengan Methode SAS.

Tahapan Refleksi. Mengadakan refleksi dan evaluasi dari kegiatan 1), 2), 3). Berdasarkan hasil refleksi dan evaluasi siklus I dibuat siklus II yang meliputi: Tahap Perencanaan Tindakan, Tahap Pelaksanaan Tindakan, Tahap Observasi, Tahap Refleksi, Tahapan Rekomendasi. Tahap ini dilakukan dengan merumuskan tindakan pembelajaran dengan Methode SAS yang tepat untuk meningkatkan prestasi belajar membaca pada siswa kelas I-A SD Negeri 106162 Medan Estate Kabupaten Deli Serdang.

Pada penelitian ini, pengumpulan data dilakukan dengan menggunakan teknik sebagai berikut: Test yang dilaksanakan melalui: Pre Test untuk pengumpulan data awal berkenaan dengan kemampuan siswa terhadap materi, Post Test setelah siswa mengikuti suatu proses perlakuan yang dilakukan peneliti, guru memberikan soal-soal post test sehingga didapatkan hasil yang akurat dan dapat menggambarkan secara jelas kemampuan awal dan akhir siswa dalam menguasai materi tersebut. Observasi, dengan menggunakan lembar observasi untuk mengumpulkan data tentang partisipasi dan aktivitas siswa dalam PBM dan implementasi pembelajaran dengan Metode SAS.

\section{HASIL PENELITIAN DAN PEMBAHASAN}

Penelitian ini dimulai dengan pemberian tes awal yang berfungsi mengukur kemampuan dasar yang dimiliki siswa dan memastikan perlu tidaknya tindakan diberikan pada materi Membaca. Berdasarkan hasil tes awal, diperoleh data sebanyak 27 orang siswa telah mampu membaca memenuhi syarat ketuntasan belajar dan 3 orang belum mencapai nilai ketuntasan belajar.Dari dua siklus tindakan yang diberikan, dapat dinyatakan bahwa ada peningkatan kemampuan siswa pada Membaca. Pada aktivitas siswa terjadi peningkatan, pada siklus 1 hanya $60,42 \%$, meningkat menjadi 91,67 pada siklus II. Pada aktivitas guru juga meningkat, dari 59,72\% pada siklus 1 menjadi 93,06\% pada siklus II. Pada Pemahaman siswa pada tes awal hanya rata-rata 50,00. Setelah dilakukan tindakan meningkat menjadi 66,50 pada siklus 1, kemudian pada siklus 2 meningkat mencapai rata-rata 90,00. Sesuai dengan indikator kinerja maka penelitian ini telah mencapai nilai aman dan penelitian tidak perlu dilanjutkan lagi. Perlu diketahui, sampai akhir siklus 2 masih ada nilai 3 orang siswa $(10,00 \%)$ belum mencapai ketuntaan minimal, sehingga diperlukan diberikan perlakuan khusus sehingga nilai siswa tersebut dapat tuntas. Dengan demikian, dari 30 orang siswa, 27 orang siswa $(90,00 \%)$ dinyatakan telah mencapai nilai ketuntasan minimal. Peningkatan ini jika dilihat dari tindakan yang dilakukan telah sesuai dengan apa yang diharapkan. Selain meningkatkan aktivitas siswa dalam pembelajaran, perasaan 
senang juga muncul dari siswa. Dan pemahaman siswa menjadi meningkat. Peningkatan ini diyakini sebagai pengaruh penerapan pembelajaran Methode SAS yang dapat meningkatkan kemampuan membaca dan daya nalar siswa.

\section{SIMPULAN} Berdasarkan hasil analisis
data dan pembahasan belajar
membaca Permulaaan dengan
methode SAS pada pelajaran Bahasa
Indonesia SDN106162 Medan Estate dapat disimpulkan bahwa pembelajaran belajar membaca Permulaaan dengan menggunakan methode SAS dilaksanakan dengan urutan: Guru bercerita atau berdialog dengan siswa, Memperlihatkan gambar yang berhubungan dengan isi cerita, Menulis beberapa kalimat sebagai kesimpulan dari isi cerita, Menulis satu kalimat yang diambil dari isi cerita, Menulis kata-kata sebagai uraian dari kalimat, Menulis sukusuku kata sebagai uraian dari katakata, Menuliskan huruf -huruf sebagai uraian dari suku-suku kata, Mensintesiskan huruf-huruf menjadi suku-suku kata, Menyatukan katakata menjadi kalimat. Pembelajaran membaca Permulaaan pelajaran bahasa Indonesia dengan menggunakan methode SAS ini dapat meningkatkan aktivitas siswa dalam pembelajaran, yang dapat mempertinggi interaksi antar siswa dan guru, serta meningkatkan pemahaman siswa terhadap membaca Permulaaan sehingga kemampuan membaca siswa meningkat. Sebagai dorongan seorang guru harus bisa memberi motivasi bagi anak yang masih kurang mampu atau kurang lancar dalam membaca untuk lebih giat berlatih dan untuk anak yang sudah lancar agar terus belajar untuk lebih giat lagi, Dengan metode SAS yang disajikan guru menggunakan media gambar-gambar, kartu kalimat, kartu kata, kartu huruf, dan papan flanel akan lebih meningkatkan kemampuan membaca.

\section{DAFTAR RUJUKAN}

Abdudurrachman, Mulyono. 2003. Pembelajaran Bahasa Indonesia SD. Jakarta: Universitas

Agus Taufiq, Hera L. Mikasa, Puji L. Prianto. 2012. Pendidikan Anak di SD,

CH Muchlissoh, MH Munif. 1992. Metode SAS Sebuah Pendekatan Bahasa Indonesia. Surabaya: PT Karya Pembina Swajaya

Depdikbud, 1994. Garis-garis Besar program Pembelajaran Bahasa Indonesia Kelas Sekolah Dasar. Jakarta: Dikdasmen.

Igak Wardani dan Kuwaya Wihardit. 2011. Penelitian Tindakan Kelas. Jakarta.

Sri Nuryati. 2007. "Pembelajaran Membaca Permulaan Melalui Permainan Bahasa di Kelas Awal Sekolah dasar". Jurnal Sekolah dasar. (Online), (www.google.com diakses tanggal 20 September 2016). 